\title{
Editorial
}

\section{Cabo de guerra entre profissionais que assistem a mulher}

\author{
Cristiane Rodrigues da Rocha*
}

Estimados profissionais da saúde e mulheres sujeitas de nossa atenção, realizei uma reflexão sobre o artigo do Dr. Raphael da Câmara Medeiros Parente, publicado no jornal do CREMERJ, em abril de 2009, que gostaria de compartilhar com o objetivo único de contribuir para o atendimento da mulher na gestação, parto e puerpério com a competência técnica e humana que merecem. Sendo assim, não estou a favor e nem contra a esta ou aquela categoria profissional. Vamos somar esforços para encontrar o equilíbrio no que parece estar sendo um "cabo de guerra" de violência verbal e prática com muitos feridos e mortos, mas sem vencedores.

Os meus 12 anos de assistência à mulher me permitem alguma experiência para fazer a análise deste contexto. Acredito, como o Dr. Raphael, que o conceito da humanização tem sido distorcido, mas não com a intenção de retirar o médico do atendimento obstétrico. A distorção ocorre para ambos os lados, dizem que o médico é desumano no seu atendimento, mas é tecnicamente bom e dizem que a enfermeira é humana, mas não tem competência técnica. Afirmativas erradas, distorcidas e sem valor real.

$\mathrm{Na}$ verdade, os médicos têm uma preocupação muito grande com as intercorrências porque eles rotineiramente devem tomar decisóes precisas e rápidas para salvar máe e/ou bebê, e por isso, o toque, a atenção e o aconchego, em muitas situaçóes, ficam para um outro momento. Que momento se as maternidades estáo cheias de mulheres para serem atendidas? É importante dizer que neste contexto o atendimento fica táo mecanizado, que mesmo quando surge a oportunidade de um atendimento humanizado (o que é raro), ele não ocorre. Mas é humano e muito humano usarmos nossos conhecimentos técnicos para atendermos prontamente à mulher e seu bebê. Apesar de sabermos que as mulheres e nós profissionais de saúde queremos muito mais que isso.

Já as enfermeiras obstetras, ou seja, a enfermeira que fez uma graduação de quatro anos e mais um ano de especialização na área obstétrica, quando atuam no parto vaginal sem distócia, possuem em sua maior parte, um tempo disponível para trabalhar aspectos de conforto físico e emocional da paciente, já que não é de sua competência partos vaginais com distócias, cesárias, curetagens, histerectomia, laqueaduras etc. As enfermeiras obstetras atendem os partos vaginais, que pelo antecedente pessoal, ginecológico e obstétrico da mulher demonstram um 
grande potencial para acontecerem sem intercorrências, e sabem que isto não garante $100 \%$ de segurança para um parto vaginal e por isso a todo momento se avalia a progressão do parto (dilatação, apagamento, integridade das bolsas, variedade de posição, altura, sangramento, contração, BCF, sinais vitais etc). Além disso, é solicitada a presença do médico para uma avaliação ou a mulher é encaminhada ao hospital de referência, caso o trabalho de parto apresente alguma alteração fisiológica.

O que ocorre é que ambos acreditam que "um atrapalha o outro" e não é verdade. Somos uma equipe! Precisamos nos ajudar e puxar o "cabo de guerra" para o mesmo lado contra o descaso e o atendimento desumano. Eu, como enfermeira obstetra, sempre trabalhei em muita sintonia com os médicos obstetras, fundamentalmente porque nos respeitávamos. Eles respeitavam o meu direito de atuar no parto e as minhas competências profissionais, como o meu Exercício Profissional permite e, assim, trabalhamos nos ajudando e propiciando uma assistência de qualidade à mulher. Os médicos, no sistema público de saúde, conseguem atender melhor os casos das mulheres que possuem patologias obstétricas e/ou clínicas, quando há enfermeiras atuando em sala de parto. E todos ganham, as mulheres que podem ter o parto vaginal com o enfermeiro obstetra que tem competência profissional, o médico que pode atender os casos de partos vaginais que apresentam algum risco e todos os procedimentos cirúrgicos ginecológicos e obstétricos. E todas as mulheres são atendidas com qualidade técnica e com maior atenção aos seus anseios.

Temos que ter a coragem de admitir o que pensamos, e não agir "cegamente", de maneira corporativa, só porque pertencemos a uma classe. Tenho certeza, que alguns médicos gostam da atuação do enfermeiro no parto vaginal sem distócia, mas não admitem porque poderiam ceder no "cabo de guerra". Por outro lado, alguns enfermeiros obstetras pensam que o enfermeiro pode e deve fazer o parto vaginal, mas sempre com uma equipe médica por perto para os casos em que se fizer necessário, mas da mesma forma, cederiam no "cabo de guerra". Não é desonroso necessitarmos uns dos outros e valorizarmos a atuação de todos como importante e indispensável para um bom atendimento. $\mathrm{O}$ que deve ficar claro é que o enfermeiro sabe identificar as intercorrências do parto vaginal, por isso solicita a equipe médica no que ele não sabe (pela especificidade da formação profissional) e/ou não pode intervir (pela Lei do Exercício Profissional).

O parto vaginal não é, e não deve ser, só do enfermeiro obstetra. Seria um prejuízo para todos a ausência do médico nesta assistência. $\mathrm{O}$ foco aqui é a conquista do respeito, digo enfatizando, do respeito, pois a conquista do direito já fora consumada. $\mathrm{O}$ aumento da atuação do médico obstetra nos partos vaginais seria festejado por todos, principalmente quando falamos de assistência privada, que é de domínio dos médicos. Quem possui plano de saúde, em sua maioria, teve condiçóes de fazer cuidados preventivos à saúde, planejar a gravidez, alimentação saudável etc. Por que então as taxas cesárias são tão altas? Só a violência, os processos e os pedidos maternos fazem ser, em algumas maternidades, as taxas maiores de $90 \%$ ?

Quando estive grávida, meu plano de saúde não cobria o atendimento pelo enfermeiro, o que me fez procurar muito por um médico que fizesse o parto vaginal. Foi apenas na quarta tentativa que encontrei. Os primeiros me falaram logo na consulta inicial que náo faziam partos vaginais, somente cirúrgicos. Será que estes foram casos isolados? Ou será que de fato muitos médicos tentam, sem motivo relevante à saúde, convencer as mulheres a realizarem o parto cirúrgico?

Então, se precisamos nos adaptar às condiçôes de ausência de segurança, vamos fazê-lo sem ônus para a mulher. Por exemplo, poderíamos ter em uma maternidade particular, no período noturno a partir das 21:00h, pelo menos um médico e uma enfermeira obstetra de plantáo. Durante o dia, o médico do pré-natal atenderia aos chamados. É cansativo? É vantajoso para o profissional? Náo sei, mas assim como o pronto atendimento faz parte da essência da profissáo que escolhemos, o atendimento de excelência também faz.

Náo acredito nos vieses dos estudos referidos pelo Dr. Rafael, pois vários deles comprovam os benefícios do parto normal e os riscos dos partos cirúrgicos. Além disso, o rigor científico 
com que a pós-graduaçáo trabalha é grande e nossos pesquisadores são éticos, mas na dúvida podemos fazer mais estudos para afirmarmos com segurança sobre o erro nos estudos dos colegas. Os estudos mostram que o parto vaginal é mais seguro que o cirúrgico em condiçôes fisiológicas, mas em situações de risco não há dúvida dos benefícios do parto cirúrgico. E quanto aos estudos sobre a casa de parto, convido os amigos médicos a realizarem, a conhecerem o trabalho das enfermeiras obstetras e ver a satisfação das clientes. Tenho convicção que vão gostar da qualidade da assistência prestada e vão querer aderir a este modelo de assistência, o que seria muito bom.

Os partos cirúrgicos a pedido devem ser discutidos por todos nós, e o nós a que me refiro não representam somente os profissionais de saúde, mas também as donas de seus corpos, as mulheres. Penso que deva ser aceito o parto cirúrgico a pedido materno sim, mas depois de uma ou mais palestras esclarecedoras sobre o procedimento e as reais vantagens e desvantagens dos dois tipos de parto. Após este esclarecimento, que ela faça um plano de parto escolhendo o tipo que melhor lhe convier, o acompanhante que deseja, os procedimentos que não deseja, Para assim avaliarmos o que é possível e o que não é possível atender. Por fim, ela assinaria um documento formalizando a sua opção, que poderia ser mudada por ela até 30 dias antes do parto. E explicaríamos a ela que o trabalho de parto é dinâmico e o que foi planejado pode ser mudado de acordo com a evoluçáo do parto. Assim, cirúrgico ou vaginal o parto seria planejado pela mulher junto ao profissional de saúde, com respeito, humanismo e segurança.

Enfim, sabemos que existem os bons e os maus profissionais em todas as áreas e categorias profissionais Por isso, se o desejo real de todos nós transcende o status social e o econômico e o objetivo é o bem de nossas mulheres e crianças, vamos nos unir em busca do equilíbrio das práticas e saberes destes missionários profissionais: o enfermeiro obstetra e o médico obstetra. As mulheres agradecem! 